\title{
Leprosy and renal transplantation
}

\author{
ANAND DATE*, GEORGE T. JOHN $\dagger$, P. P. THOMAS \\ \& C. K. JACOB \\ Departments of *Pathology \& Nephrology, Christian Medical \\ College \& Hospital, Vellore 632004, India
}

Accepted for publication 7 December 1997

Summary Nine cases of leprosy in patients treated at a large renal transplant centre in South Asia are described. Three had leprosy diagnosed before transplantation and had either completed or were continuing chemotherapy at the time of transplantation. One showed exacerbation of undisclosed leprosy after transplantation. Five patients developed the disease for the first time 22 months to 12 years after transplantation. Immunosuppression did not adversely affect the treatment of leprosy in any of the patients though concurrent liver disease required cessation of rifampicin in one patient.

\section{Introduction}

Renal transplantation is now available for treatment of chronic renal failure in many hospitals in tropical areas where leprosy is endemic. Also, renal disease is an important cause of morbidity and mortality in patients with leprosy, ${ }^{1,2}$ therefore, leprosy is a disease to be considered in tropical renal transplant programmes.

Presented below is the experience with leprosy at the largest renal transplant centre in South Asia where 1667 patients have received transplants so far. Patients from all parts of India, Bangladesh, Nepal and Sri Lanka are treated. Approximately $90 \%$ are followed up for 1 year after transplantation and then referred to the care of local physicians. Many do not return for regular follow-up and treatment of complications. At times, patients who had received their transplants elsewhere are referred here for treatment. The cases described below include the first leprosy patient reported to be accepted as a renal transplant recipient. ${ }^{3}$

\section{Leprosy diagnosed before transplantation}

PATIENT NO. 1

A female patient was diagnosed to be having systemic lupus erythematosus at the age of 19

† Correspondence 
years. She was on treatment with prednisolone and azathioprine for 4 years when she developed an anaesthetic patch on the elbow with ulnar nerve thickening. A biopsy showed borderline-tuberculoid leprosy for which she took dapsone for 5 years. During this period steroids were continued but azathioprine was discontinued. When next seen in the hospital the patient was 40 years old and showed no evidence of leprosy; but had chronic renal failure. She received an allograft from her mother which was rejected. A transplant from an unrelated donor was then performed, at another hospital. Antirejection therapy was with high doses of steroids and azathioprine, to which cyclosporin A (CsA) was added after the second transplant. There was no recurrence of leprosy at the time of death a year later.

\section{PATIENT NO. 2}

A male with chronic renal failure due to IgA nephropathy received a renal transplant from his brother when he was 28 years old. Thirteen months prior to the transplant the patient developed an anaesthetic patch on the back diagnosed to be tuberculoid leprosy and received dapsone for one year. His father had leprosy but was not living with the family for 15 years. This story was forthcoming only when an exacerbation of the disease was noted two years post-transplant, and he was restarted on dapsone. When he was last seen at follow up 2 years after the transplant he was well.

\section{PATIENT NO. 3}

A 42-year-old male, reported in detail earlier, ${ }^{3}$ had end stage diabetic nephropathy for which he received a renal transplant from his sister. Five months earlier the patient noticed an anaesthetic patch on the back, which was diagnosed as tuberculoid leprosy and treated with dapsone. Dapsone was continued after the transplantation. Post-transplant immunosuppression was with prednisolone and azathioprine. The leprous lesion showed no sign of activity in spite of enhanced immunosuppression for an episode of acute rejection and appeared completely healed with the continuing dapsone therapy at his death from chronic rejection one year after transplantation.

\section{Leprosy untreated before transplantation}

\section{PATIENT NO. 4}

A female with chronic renal failure of unknown aetiology was 40 years old when she received a renal allograft from an unrelated donor. Post-transplant immunosuppression was by prednisolone and azathioprine. Six and a half years later she developed anaesthetic erythematous skin patches on the left forearm diagnosed as borderline-lepromatous leprosy and erythema nodosum leprosum. The patient admitted having noticed hypoanesthetic, hypopigmented patches at the same site 6 months prior to transplantation, for which she had not taken treatment. She was put on multidrug chemotherapy with dapsone, rifampicin and clofazamine and advised to continue the treatment for 5 years. Rifampicin was withdrawn due to chronic liver disease. This patient died of liver cell failure hepatitis B virus (HBV) related 4 years after the diagnosis of leprosy. 


\section{Leprosy first manifesting after transplantation}

PATIENT NO. 5

A male with chronic renal failure of unknown aetiology received a renal transplant at the age of 37 years, from his father. After having been on immunosuppression with prednisolone and azathioprine for 22 months he developed nodules, widely distributed over the body. A biopsy of one of these showed histoid leprosy. There was no history of leprosy in the past or contact with leprosy. He was discharged from hospital after having been started on dapsone, clofazamine and rifampicin and advised to continue chemotherapy at a hospital near his home. Follow-up information is not available.

\section{PATIENT NO. 6}

A male received a renal transplant from his brother, for chronic renal failure due to end stage renal failure of unknown aetiology, when he was 39 years old. Immunosuppression was with prednisolone and azathioprine. Six years after transplantation he developed diffuse erythematous papules diagnosed as lepromatous leprosy and was treated with dapsone, clofazamine and rifampicin. This patient also did not have leprosy earlier, nor contact with leprosy. $\mathrm{He}$ returned home to continue treatment. Follow up information is not available.

PATIENT NO. 7

A male received a renal allograft for end stage membranoproliferative glomerulonephritis type 1 , when he was 48 years old, from his brother. The patient received prednisolone and azathioprine immunosuppression. Seven years later he developed a large hypoanaesthetic patch on the leg which was diagnosed as borderline-tuberculoid leprosy. His father had leprosy 25 years earlier. Treatment with dapsone, clofazamine and rifampicin was started and the patient was discharged to return home with the advice to continue chemotherapy under the care of a local physician. Follow-up information is not available.

PATIENT NO. 8

A female with end stage renal disease of unknown aetiology received a renal allograft from her brother, when she was 26 years old. One year after transplantation she developed abnormal liver function with HBV and active cytomegalovirus infection. Six years later while on maintenance immunosuppression with prednisolone and azathioprine she presented with multiple skin lesions diagnosed as borderline-lepromatous leprosy with erythema nodosum leprosum. There was no past history of leprosy or known contact with the disease. Treatment was started with dapsone, rifampicin and clofazamine. Chemotherapy was discontinued because of worsening liver function and replaced with dapsone and clofazamine alone when liver function tests improved. The patient died of chronic liver disease ten and a half years after transplantation. At the time of death there was no clinical evidence of leprosy for which she was still being treated.

PATIENT NO. 9

A male received a renal allograft from his daughter, in another hospital when he was 48 years 
old. The disease causing chronic renal failure was not known. He was on immunosuppression with prednisolone, azathioprine and cyclosporin A. Twelve years later the patient was referred to this hospital with good renal function but with infiltrated lesions of the face and ears; without nerve thickening. Skin smears from the ears, cheek, arms and back showed large numbers of lepra bacilli. A diagnosis of lepromatous leprosy was made. This patient also did not give a past history of leprosy or contact with the disease. The patient was started on dapsone, rifampicin and clofazamine. He continued treatment with periodic checkups. CsA level was done 10 days after rifampicin was within the normal range. Patient did not have acute rejection episode after starting MDT. The bacterial indices and skin lesions had improved at last follow up after 30 months.

\section{Discussion}

Leprosy in relation to renal transplantation features in reports from Western centres as a diagnostic conundrum occurring unexpectedly in emigrant patients. ${ }^{6}$ It also features as a response to news of patients with leprosy being used as renal donors and expressing a rightful indignation against their exploitation by the donor kidney trade. ${ }^{8}$ Less understandable is the unexpressed exaggerated fear of this disease ${ }^{8}$ especially when keeping in mind that leprous granulomas are extremely rare in the kidney, ${ }^{2}$ that the disease is amenable to treatment, and less communicable, and less likely to be resistant to chemotherapy than tuberculosis.

The different associations shown by the cases presented above, have been described earlier. A number of patients with known active or inactive leprosy have undergone renal transplantation. Patients with lepromatous disease ${ }^{4}$ on antileprosy chemotherapy at the time of transplantation showed continued healing of leprosy, despite immunosuppression. The same is true for patients in the tuberculoid end of the leprosy spectrum as in cases 1 and $3 .^{3}$ Patients who have completed chemotherapy at the time of transplantation may not have a recurrence as in case 1 , and even if the disease was of the lepromatous type. ${ }^{4,5}$ Recurrence has however been reported. ${ }^{6}$ Untreated or incompletely treated disease may exhibit an unexpected exacerbation ${ }^{7}$ as in cases 4 and 2 respectively. Continuation of antileprous chemotherapy is required if there is incomplete or inadequate treatment before transplantation. We do not practice or recommend secondary chemoprophylaxis.

Leprosy may be diagnosed for the first time after transplantation, ${ }^{10}$ as in cases 5 to 9 presented here. Such patients may or may not have been in contact with leprosy, ${ }^{4}$ as in four of the five cases presented above. Though infection after transplantation cannot be excluded, the natural history of leprosy makes it possible that some of these patients had unrecognised latent leprosy which manifested as a result of immunosuppression.

Cases 4 and 8 demonstrate the problem of antileprosy chemotherapy in the presence of liver disease which is an important cause of morbidity and mortality in renal transplant patients. The decision to discontinue rifampicin is difficult, but as seen in our patient, may not seriously affect the course of the disease. In such a situation there are no guidelines regarding the duration of antileprosy chemotherapy. When unhindered multidrug therapy is possible the current recommendations regarding duration should suffice.

In our limited experience of MDT with a CsA treated patient there was no adverse effect on graft function due to rifampicin-CsA interaction; dapsone and clofazamine have no such reported interaction. However prednisolone dose was doubled in those receiving rifampicin as part of the MDT. 
Table 1. Clinical details of patients with leprosy and kidney transplant

\begin{tabular}{|c|c|c|c|c|c|c|c|c|c|}
\hline Pt No. & $\begin{array}{l}\text { Age at } \\
\text { diagnosis }\end{array}$ & $\begin{array}{c}\text { Renal } \\
\text { disease }\end{array}$ & Immunosupprn. & $\begin{array}{l}\text { Leprous } \\
\text { skin }\end{array}$ & $\begin{array}{l}\text { Leprous } \\
\text { N. lesion }\end{array}$ & $\begin{array}{l}\text { Skin } \\
\text { biopsy }\end{array}$ & $\mathrm{BI}$ & Treatment & $\begin{array}{l}\text { Follow-up } \\
\text { after treatment }\end{array}$ \\
\hline \multicolumn{10}{|c|}{ Leprosy diagnosed before transplantation } \\
\hline 1 & 23 & SLE & PCA & $\begin{array}{l}\text { Single } \\
\text { anaesthetic }\end{array}$ & $\begin{array}{l}\text { R. ulnar N. } \\
\text { thick }\end{array}$ & BT & Neg. & $\begin{array}{l}\text { DDS } 100 \mathrm{mg} \\
5 \text { years }\end{array}$ & $\begin{array}{l}\text { No recurrence } \\
1 \text { year. Died of CRF }\end{array}$ \\
\hline 2 & 26 & $\operatorname{Ig} \mathrm{A}$ & PA & $\begin{array}{l}\text { Single } \\
\text { anaesthetic }\end{array}$ & Normal & $\begin{array}{l}\text { Chronic } \\
\text { inflamm. }\end{array}$ & Neg. & $\begin{array}{l}\text { DDS } 100 \mathrm{mg} \\
2 \text { years }\end{array}$ & $\begin{array}{l}\text { Well } 2 \text { years } \\
\text { LFU }\end{array}$ \\
\hline 3 & 42 & DN & PA & $\begin{array}{l}\text { Single } \\
\text { hypoesthetic }\end{array}$ & Normal & $\begin{array}{l}\text { Indeterm. } \\
\text { leprosy }\end{array}$ & NA & $\begin{array}{l}\text { DDS } 100 \mathrm{mg} \\
1 \text { year }\end{array}$ & $\begin{array}{l}\text { Well } 1 \text { year } \\
\text { Died of CRF }\end{array}$ \\
\hline \multicolumn{10}{|c|}{ Leprosy untreated before transplantation } \\
\hline 4 & 47 & ESRD & PA & $\begin{array}{l}\text { Ill defined } \\
\text { anaesthetic } \\
\text { patches }\end{array}$ & $\begin{array}{l}\text { L. ulnar N. } \\
\text { thick }\end{array}$ & BL, ENL & 1.25 & $\begin{array}{l}\text { R } 6 \text { months } \\
\text { C,DDS } \\
2 \text { years }\end{array}$ & $\begin{array}{l}\text { Improved } 4 \text { years } \\
\text { Died of LCF }\end{array}$ \\
\hline \multicolumn{10}{|c|}{ Leprosy first manifesting after transplantation } \\
\hline 5 & 37 & ESRD & PA & $\begin{array}{l}\text { Multiple } \\
\text { nodules }\end{array}$ & Normal & Histoid L & 3 & MDT & $\begin{array}{l}\text { Improved } 10 \mathrm{mo} \text {. } \\
\text { LFU }\end{array}$ \\
\hline 6 & 45 & ESRD & PA & $\begin{array}{l}\text { Multiple } \\
\text { erythematous } \\
\text { papules }\end{array}$ & Normal & LL & 5.5 & MDT & LFU \\
\hline 7 & 55 & MCGN-I & PA & $\begin{array}{l}\text { Anaesthetic } \\
\text { patches leg }\end{array}$ & Normal & $\mathrm{BL}$ & NA & MDT & $\begin{array}{l}\text { Improved } 7 \text { mo. } \\
\text { LFU }\end{array}$ \\
\hline 8 & 32 & ESRD & PA & $\begin{array}{l}\text { Multiple } \\
\text { hypopigm. } \\
\text { patches }\end{array}$ & Normal & LL & 4.65 & C,DDS & $\begin{array}{l}\text { Improved } 4 \text { years } \\
\text { Died of LCF }\end{array}$ \\
\hline 9 & 60 & ESRD & PCA & $\begin{array}{l}\text { Multiple } \\
\text { hypopigm. } \\
\text { patches. ENL }\end{array}$ & Normal & LL & 4.5 & MDT & $\begin{array}{l}\text { Improved at } \\
30 \text { months }\end{array}$ \\
\hline
\end{tabular}

BI—Bacterial Index; SLE—systemic lupus erythematosus, DN—diabetic nephropathy; ESRD—end stage renal disease; MCGN—mesangiocapillary glomerulonephritis;

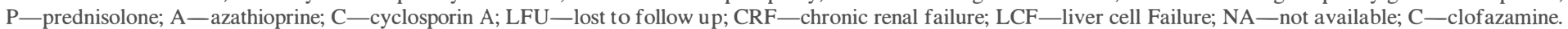


Leprosy occurs later in the post-transplant period than tuberculosis. ${ }^{9}$ Patients on CsA immunosuppression manifest tuberculosis earlier than those not receiving it. ${ }^{10}$ There is insufficient data to comment on the effect of CsA on leprosy. Acquired immune deficiency syndrome with profound T-cell suppression is not associated with a higher incidence of leprosy, ${ }^{11}$ indicating CsA immunosuppression and its attendant T-cell depression is unlikely to exacerbate the disease.

\section{References}

${ }^{1}$ Date A. The immunological basis of glomerular disease in leprosy-a brief review. Int J Lepr Other Mycobact Dis 1982; 50: 351-354.

2 Date A, Harihar S, Jeyavarthini SE. Renal lesions and other major findings in necropsies of 133 patients with leprosy. Int J Lepr Other Mycobact Dis 1985; 53: 455-460.

${ }^{3}$ Date A, Mathai R, Pandey AP, Shastry JCM. Renal transplantation in leprosy. Int J Lepr Other Mycobact Dis 1982; 50: 56-57.

${ }^{4}$ Roselino AM, de Almeida AM, Foss NT, Lima VJ, Raspanti EO, Ferraz AS. Renal transplantation in leprosy patients. Int J Lepr Other Mycobact Dis 1993; 61: 102-105.

5 Mocelin AJ, Ajzen H, Ancao MS, Stabile NC, Sadi A, Maluli AM, Ramos OL. Kidney transplantation in leprosy. Transplantation 1979; 28: 260.

6 Teruel JL, Liano F, del Hoyo M, Rocamora A, Mampaso EG, Quereda C, Ortuno J. Successful kidney transplantation in leprosy and transitory recurrence of the disease. Int J Lepr Other Mycobact Dis 1985; 53: $410-411$.

7 Adu D, Evans DB, Millard PR, Calne RY, Shwe T, Jopling WH. Renal transplantation in leprosy. Br Med J 1973; 2: 208-211.

8 Dausset J, Rapaport F. Criminal hazards of human organ traffic. Transplant Proc 1996; $28: 42$.

9 John GT, Date A, Vincent L, Jacob CK, Shastry JCM. A time-table for renal transplantation in the tropics. Transplantation 1996; 61: 972-973.

10 John GT, Vincent L, Jeyaseelan L, Jacob CK, Shastry JCM. Cyclosporin A and mycobacterial infection. Transplantation 1994; 58: 247-249.

11 Lucas S. Human immunodeficiency virus and leprosy. Lepr Rev 1993; 64: 97-103. 